\title{
SAVING THE TUROPOLJE PIG IN CROATLA,
}

\author{
H.-P. Grunenfelder', G. Gugic' and F. Punz3 \\ 'Pro Specie Rara, Schneebergstr. 17, CH-9000 St.Gallen, SWITZERLAND \\ 'Projectleader SAVE/Euronatur, Suvoj 40, HR-44213 Kratecko, CROATIA \\ 3SAVE-coordination, Tullnerstr. 18, A-3423 St.Andra-Wérdern, AUSTRIA
}

\section{SUMMARY}

On the front lines of Croatia's war areas live the Turopolje pigs, in danger of extinction. Immediate action is sorely needed. The new European Foundation SAVE (Safeguard for Agricultural Varieties in Europe), an umbrella organization for the in-situ conservation of agricultural genetic resources, has started an international rescue project. The remaining pigs are listed and will be regrouped for a mating program, which avoids inbreeding. For an additional insurance, SAVE will also bring new breeding groups away from the front lines in, and outside of, Croatia. A breeding register has been set up provisionally at the herdbook office for endangered breeds with Pro Specie Rara in St.Gallen, Switzerland.

Key words: Genetic Resource s, Pig, Croatia

\section{RESUME}

En Croatie, entre les frontiéres de guerre, la race porcine du, Touropoije a tenement diminuée, qu'elle est menacée d'extinction. Une action immédiate est nécessaire. La nouvelle fondation européenne SAVE (Safegard pour I'Agriculture des Variétés d'Europe), une organisation faitière pour la conservation in-situ, a commencé un projet pilote international. Les porcins existants sont registrés et seront regroupés pour un programme d'accouplement, qui évite la consanguinity. Pour la sécurité additionnelle SAVE est en train de créer des nouveaux groupes d'élevage loin des zones de guerre, en arriére-Croatie et mème A 1'étranger. Le registre de troupeau (herdbook) est administré provisoirement par la Fondation Pro Specie Rara, qui s'occupe A St.Gall/ Suisse du registre des troupeaux de bétail menacé.

Mots clés : Ressources génétiques, porc, Croatie 


\subsection{INTRODUCTION}

The most valuable genetic and cultural heritages of biological diversity have survived primarily in marginal lands, with ethnic minorities or in barely accessible areas, i.e. in regions of high ecological adaptability and low pressure to change. This inheritance is particularly threatened in times of war or economic and political turmoil. The last of the Turopolje Pigs live on the front lines in Croatia between the Croatians and the Kraina Serbs and are in danger of being wiped out. In a war situation where people need help, it may, at first sight, seem cynical to work for the preservation' of a breed of farm animals. It must be clearly stated, however, that this sensitive project will especially help the local people to maintain one of the bases of their present and future survival. Furthermore, when the war broke out in October 1990, preservation measures were already being discussed and were postponed at that time. If we don't act now - while the front lines are "frozen" - there won't be anything left to rescue.

\subsection{CHARACTERISTICS OF THE BREED, HUSBANDRY AND USE}

The Turopolje belong to the bacon pigs. The curly-haired animals are similar to the Swallowbelly Wooly Pig; they are grey-white-yellow with 5-9 saucer-sized black spots. The Turopolje are uncommonly hardy pigs, able to overwinter outdoors and forage extensively for themselves. They can survive on a minimal diet, with sows losing up to $50 \%$ of their body weight during the nursing period if need be.

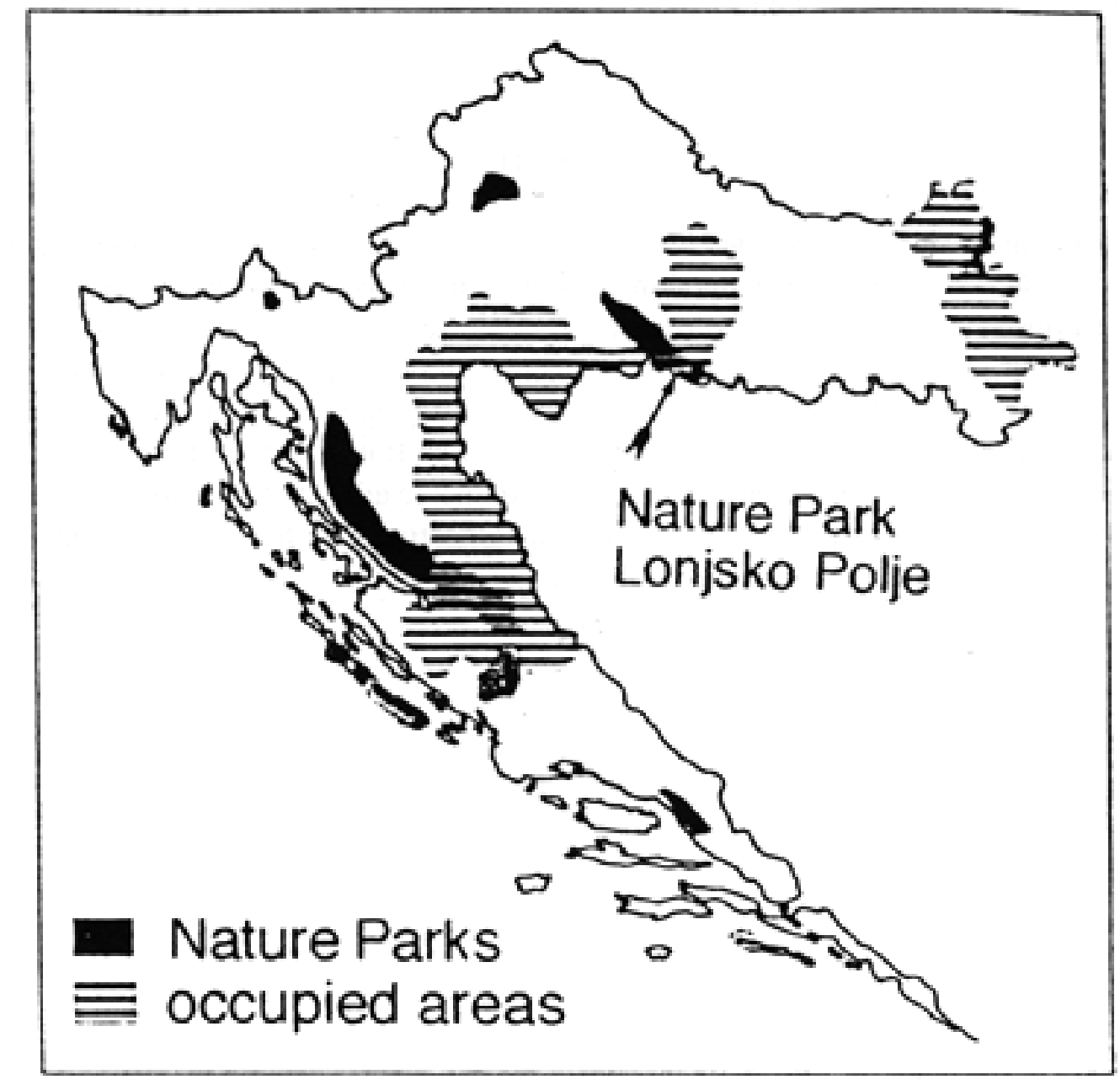




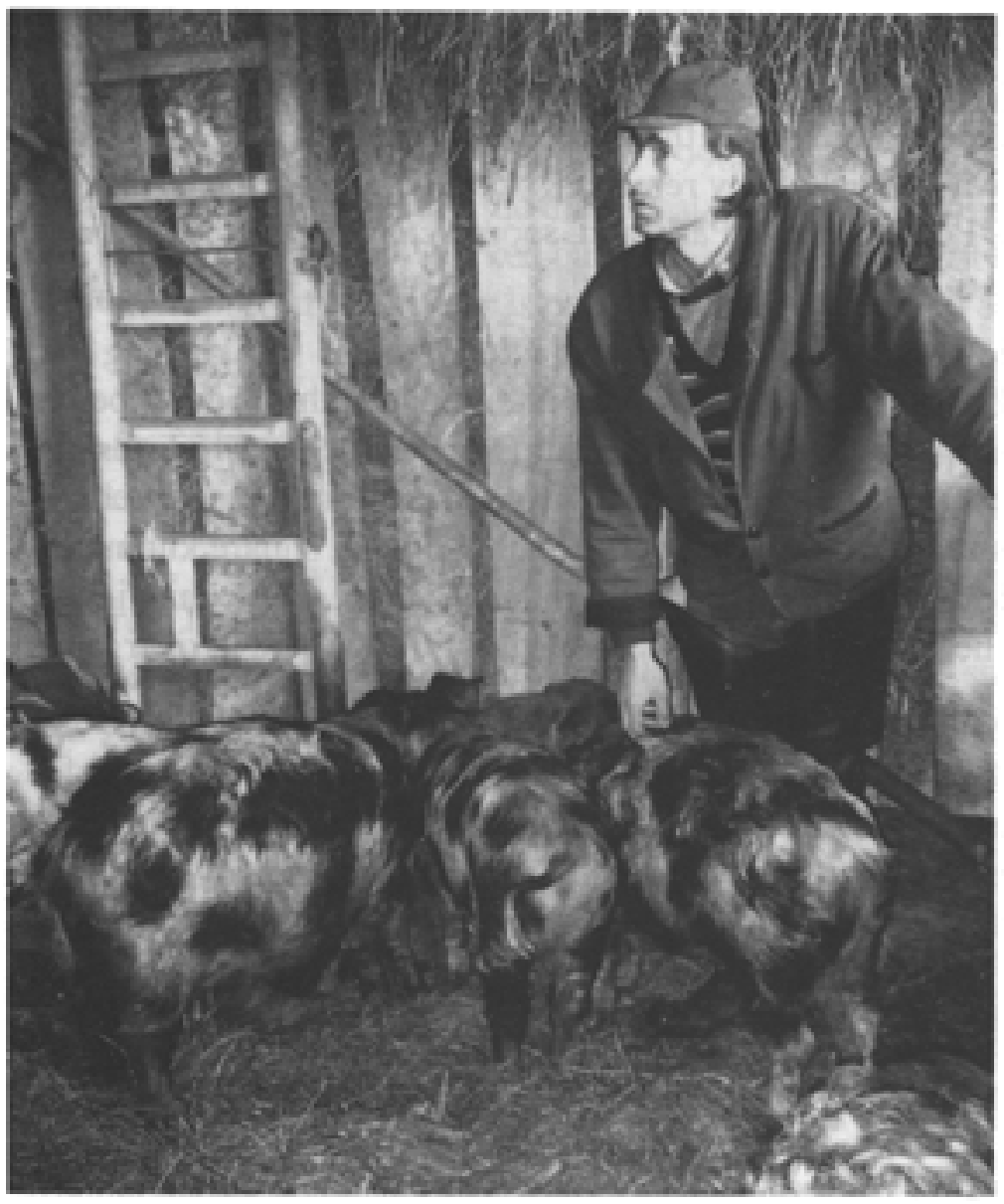

Breeding group at Kratecko

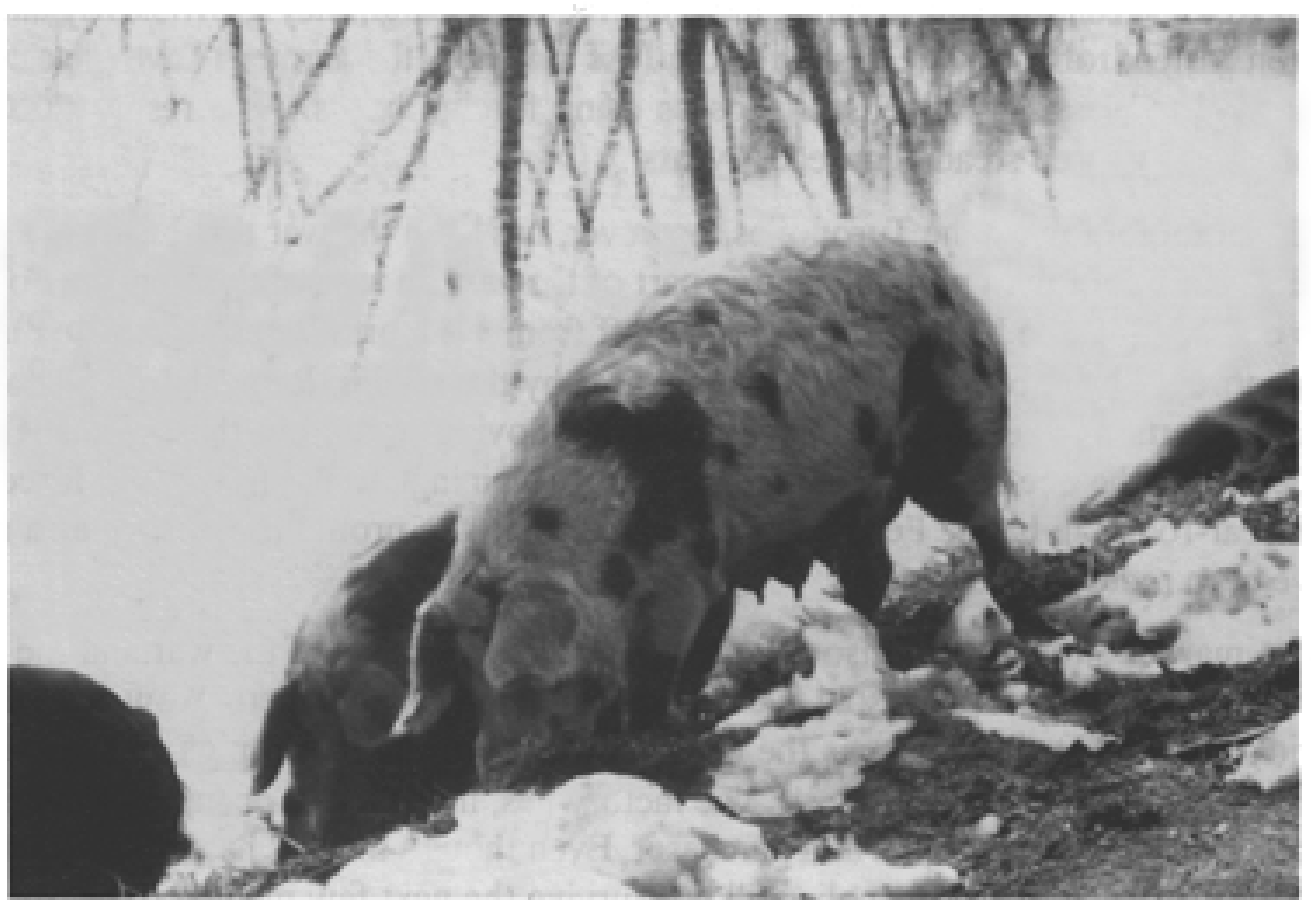

Sows in winter

\section{AGRI 14}

Downloaded from https:/www.cambridge.org/core. University of Basel Library, on 11 Jul 2017 at 15:02:18, subject to the Cambridge Core terms of use, available at https:/www.cambridge.org/core/terms. https://doi.org/10.1017/S1014233900000316 
The Turopolje has adapted itself optimally to its life in the river bottom lands; this strain of slow-matuiing bacon pig was previously found along the entire length of the Sava River in Slovenia and Croatia. The Kraina Landpig has almost died out on the upper reaches of the river. In Mddle Croatia, between Zagreb, Sisak and Nova Gradiska, tiny remnants of the Turopolje have survived until today primarily in the Lonjsko Polye Nature Park and sporadically in the neighboring Odransko Polje.

The forester and wildlife biologist Goran Gugic has minutely studied the keeping and exploitation of pigs in the unoccupied part of the Lonjsko Polje Nature Park; this is described in his thesis, "Swine Husbandry and Sylvan Forage in Lonj sko Polje" (Munich, 1992). This preserve threatens to lose much of its ecological value if the natives lose their traditional extensive agriculture with old varieties: the pigs roam freely in the periodically flooded, square kilometersized communally-used grazing meadows and hardwood bottom lands. Since the prohibition of swine foraging in forests throughout the rest of Europe, the management of the Sava river lands today is unique.

The free-ranging pigs are an attraction of the nature park. They root in shallow water for food, enjoy cracking large fresh-water mussels and keep the shallows free of vegetation. Their rooting in the meadows breaks up old grass and helps fresh grass to sprout. They improve the food chain in the riverain woods and the physical characteristics of hydromorphic soils. At night, the pigs are not herded into the villages, but are placed in pigsties in the meadows or forests. They respond only to the specific calls or whistles of their herders.

\subsection{THE DANGER}

The Turopolje overcome the hardships of their regularly flooded environment outstandingly. They swim well and can overwinter in the open. On the other hand, they grow slowly and produce more bacon instead of the ham desired today. As a result, the farmers- have repeatedly tried introducing other less hardy breeds or crosses using foreign boars. As a result, the Turopolje population has decreased steadily in recent years..

The greatest blow to the Turopoljes, however, has been the war that broke out in Croatia in 1991. The entire southern part and a large part of the eastern area of the Lonjske Polje Nature Park was occupied by the Kraina Serbs and cut off from the Northeastern part (see map). Since then, this entire area has been used as a staging area by the armies. Regular troops, paramilitary bands and all sorts of questionable people are now moving around in this region. These have severely decimated the free-roaming pig herds and the remaining farmers have been forced to keep their pigs year-round in barns. Feed costs are higher than the profits from sales; as a result, the herds have been reduced even further.

The market situation has also changed completely because of the war and the economic crisis. Previously, the Turopolje sold well to the middle-class butchers (now ruined) and the Gavrilovic sausage factory. This was the chief purchaser of the bacon pigs and made the wellknown Gavrflovic salanii out of their flesh. The factory lies, however, in occupied Petrinj a and, for the time being, is out of the question as a purchaser. Even though there is hardly any fighting along the front at the moment, the Turopolje will not survive the next few months if measures are not taken quickly.

\subsection{THE RESCUE PLAN}

The nature protection foundation Euronatur has been active for years in the Lonjsko Poije Nature Park. It was already clear in 1990 that the wide expanses there could be protected only through the maintenance of the traditional agriculture and the preservation of the old robust breeds. An agricultural concept worked out by the wildlife biologist Goran Gugic can be fwly implemented, however, only after the war is over. In the meantime, an emergency program is necessary: 
- Euronatur will, in order to preserve the old meadow husbandry, support the Turopoijes locally by paying the farmers a premium to help keep pure-blooded animals in their barns. A marketing plan will also be developed.

- SAVE will take on the additional insurance of building up new breeding groups away from the front fines in, and outside of, Croatia; they will assist the breeding programs technically. A herd book (breeding register) containing all desirable animals shall be established. Great weight will be put on the use of good breeding boars. Further remnant populations are being sought

\subsection{FIRST SUCCESSES}

The first animals were assessed and marked in the Sava meadows in early January, 1994. The Tiergarten Schoenbrunn in Vienna arranged for 3 young boars and 3 young sows to be transported to the Zagreb Zoo; these are the first breeding groups safely away from the front lines. The buying up of pure-bred young animals is not to be underestimated as a signal for the villagers: "Something is happening and the traditional breed is finally valued again!"

In the meantime Goran Gugic has made the inventory of the relipopulation and set up the breeding register. With a mating program which avoids inbreeding, the Turopolje pig may rise again. We cannot let these initial successes fool us, however. The way to the goal is a long and delicate process. 




Transport of pig at the Zagreh Zoo

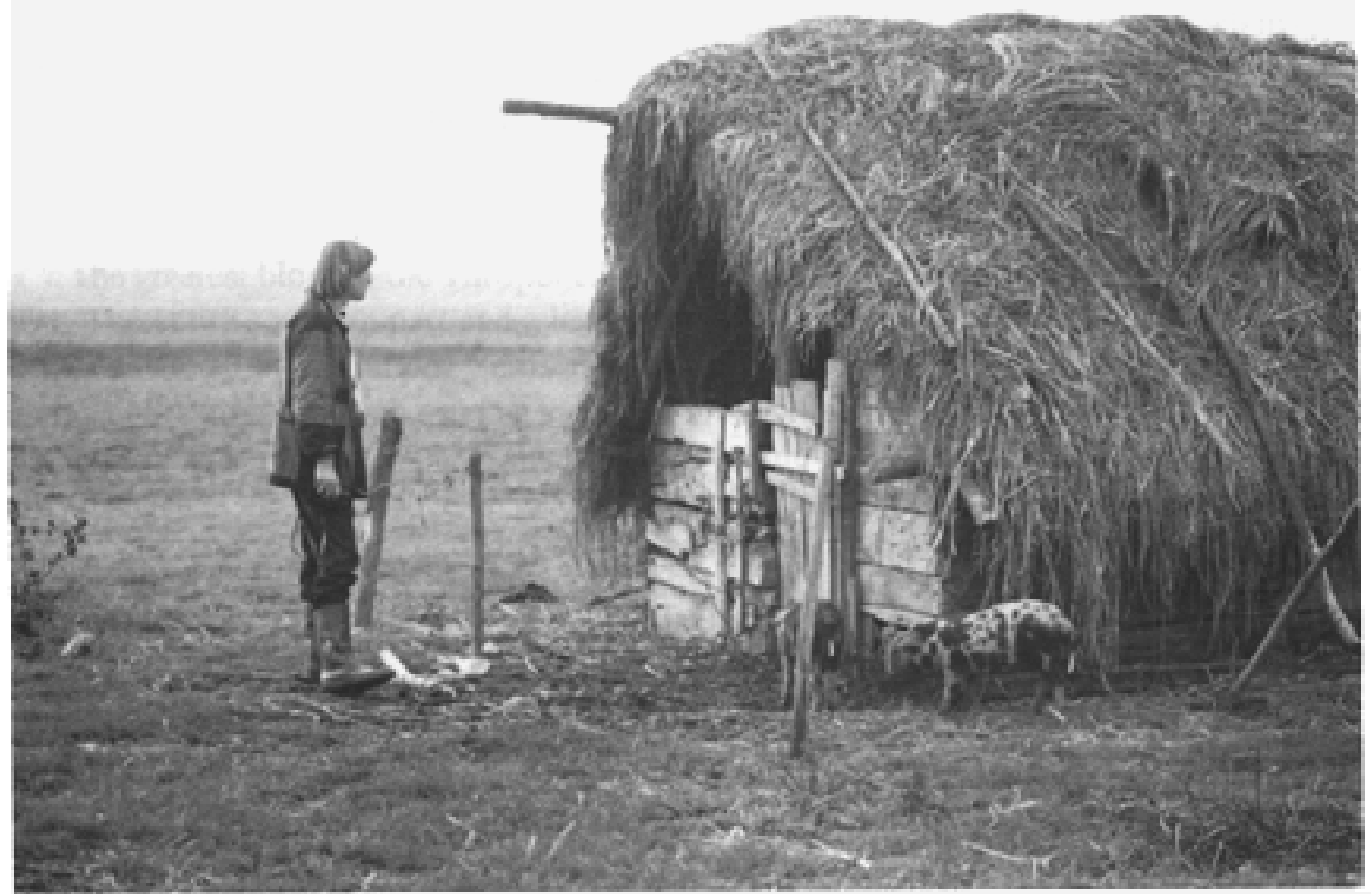

Pigstic in Sara meadows 